\title{
A Measuring Device for the Checking of 3D Indicators
}

\author{
Š́rka Tichá1, Ondřej Srba², Jan Vavřina ${ }^{2}$ \\ ${ }^{1}$ Department of Machining, Assembly and Engineering Metrology, Faculty of Engineering, VŠB-Technical University of \\ Ostrava. 17. listopadu 15/2172, 70833 Ostrava-Poruba. Czech Republic. E-mail:sarka.ticha@vsb.cz \\ ${ }^{2}$ UNIMETRA Company Ltd., Těšínská 773/396, 71600 Ostrava-Radvanice, Czech Republic. E-mail: ondrej.srba@uni- \\ metra.cz, jan.vavrina@unimetra.cz
}

This paper was based on the cooperation the Department of Machining, Assembly and Engineering Metrology with company accredited by Czech Institute for Accreditation. It deals with issues of calibration 3D indicators. Generally, the calibration of non-specified working gauges integral part of every company, which uses such gauges. Checking/calibration of measuring instruments is important for ensuring the uniformity and accuracy of measurements to ensure continuity of measurement results. The paper deals with streamlining the process of calibration of indicators 3D design and practical verification of appropriate gauge for the calibration. The target of innovation is to eliminate the errors and shortcomings of the current solutions. In the conclusion are the results of calibration by help current and new solution checking device and their comparison.

Keywords: 3D indicator, calibration, checking device, calibration procedure

\section{Acknowledgement}

This work was supported by the European Regional Development Fund in the IT4 Innovations Centre of Excellence project CZ.1.05/1.1.00/02.0070 and by Education for Competitiveness Operational Programme financed by Structural Founds of Europe Union in project Integrita CZ.1.07/2.3.00/20.0037 and by Student Grant Competitions SP2015/116 and SP2015/129 financed by the Ministry of Education, Youth and Sports and Faculty of Mechanical Engineering V̌̌B-Technical University of Ostrava.

\section{References}

[1] SRBA, O. (2013). Calibration of the 3D Taster. Thesis. Ostrava: VŠB-TU Ostrava, 100 p.

[2] Document EA4/02. (2013). Evaluation of the uncertainty of measurement in calibration. Prague: Czech Standards Institute, $70 \mathrm{p}$.

[3] ČSN EN ISO 10012-1. (2003). Quality assurance requirements for measuring equipment - Part 1: Metrological confirmation system for measuring equipment. Prague: Czech Standards Institute, $27 \mathrm{p}$.

[4] ČSN EN ISO 9493. (2011). Geometrical product specifications (GPS) - Dimensional measuring equipment: Dial test indicators (lever type) - Design and metrological characteristics. Prague: The Office for Standards, Metrology and State Testing, $27 \mathrm{p}$.

[5] ČSN EN ISO 463. (2006). Geometrical product specifications (GPS) - Dimensional measuring equipment - Design and metrological characteristics of mechanical dial gauges. Prague: Czech Standards Institute, 18 p.

[6] JANOŠ, M., MRKVICA, I. (2010). Design of Jig for Turbo-blower Support Machining. Návrh př́ipravku pro obrábění podpěr turbodmychadel. Strojírenská technologie. Volume XIV. Special issue. Ústí nad Labem: UJEP Ústí nad Labem, pp. 96-99. ISSN 1211-4162

[7] KOBAYOSHI, M., CHUI, Q. S. H. (2005). The positioning influence of dial gauges on their calibration results. Measurement Journal of the International Measurement Confederation. Volume 38. Issue 1. São Paulo: Elsevier Ltd., pp. 67-76. ISSN 263-2241

[8] MARTíN, M. J., FLORES, I., SEBASTIÁN, M. Á. (2009). Analysis of standards and specific documentation about equipment of dimensional metrology. 3rd Manufacturing Engineering Society International Conference. MESIC 2009. Alcoy-Spain: June 2009, pp. 213-221. ISSN 0094243X. ISBN 978-073540722-0 